\title{
TECHNOLOGY SOURCING VERSUS TECHNOLOGY EXPLOITATION: AN ANALYSIS OF US FOREIGN DIRECT INVESTMENT FLOWS
}

\author{
James H Love \\ Aston Business School
}

October 2000

Acknowledgement: I am grateful for the research assistance provided by Chris Anthony and for the detailed comments of David Saal and Nigel Driffield. 


\section{Abstract}

The traditional paradigm of foreign direct investment suggests that FDI is undertaken principally to exploit some firm-specific advantage in a foreign country which provides a locational advantage to the investor. However, recent theoretical work suggests a model of FDI in which the motivation is not to exploit existing technological advantages in a foreign country, but to access such technology and transfer it from the host economy to the investing multinational corporation via spillover effects. This paper tests the technology sourcing versus technology exploiting hypotheses for a panel of sectoral FDI flows between the United States and major OECD nations over a 15 year period. The research makes use of Patel and Vega's (1999) taxonomy of sectors which are likely $a$ priori to exhibit technology sourcing and exploiting behaviour respectively. While there is evidence that FDI flows into and from the United States are attracted to R\&D intensive sectors, very little support is found for the technology sourcing hypothesis either for inward or outward FDI flows. The results suggest that, in aggregate, firm-specific 'ownership' effects remain powerful determinants of FDI flows. 


\section{Introduction}

The role of technology in foreign direct investment (FDI) is a source of some ambiguity. Within the dominant 'eclectic paradigm' (Dunning, 1988) the role of technology seems clear enough. The paradigm suggests that where a company has some 'ownership' (i.e. competitive) advantage over its rivals, and where for reasons of property rights protection licensing is unsafe, a company will set up production facilities in a foreign country through FDI, as long as there are specific advantages in the host country which make FDI preferable to exporting. Since much of the discussion of ownership advantages is couched in terms of technology and/or management expertise, there is therefore a strong a priori assumption that FDI will be an important method by which technology is transferred internationally from home to host countries.

However, recent theoretical work has given renewed impetus to something long recognised in the literature, that a possible motive for FDI is not to exploit proprietary technology, but to access it: thus technology sourcing may be the motive for FDI. For example, Fosfuri and Motta (1999) question the need for firm-specific advantages to give rise to multinational activity, and provide a formal model of FDI in which the motivation is not to exploit existing technological advantages in a foreign country, but to access such technology and transfer it from the host economy to the investing multinational corporation via spillover effects. This possibility has had some policy influence in the United States and Europe, with concerns that the technological base of these economies may be at risk through the technology sourcing activities of Japanese and US corporations respectively (Kogut and Chang 1991; Neven and Siotis 1996)

The recent literature on the internationalization of $R \& D$ suggests that this concern may be well placed (Cantwell, 1995; Cantwell and Janne 1999; Kuemmerle, 1999a, 1999b; Patel and Vega, 1999). This literature stresses a range of reasons for FDI in $R \& D$, much of which is concerned with the relative technological strengths of the capital exporting (i.e. 'home') firm or country versus that of the host. The evidence suggests that corporations are increasingly moving their R\&D facilities abroad, and 
that this is being done as part of a strategic move away from merely adapting 'core' technology to a foreign market towards a much more central role in product innovation and development. In addition, the literature suggests that there is a growing willingness to locate such facilities close to leading centres of research and innovation specifically with a view to absorbing learning spillovers from geographical proximity to such sites (Pearce, 1999; Niosi, 1999; Serapio and Dalton, 1999).

This paper adds to the debate by performing a panel analysis of manufacturing FDI flows between the United States and its major recipient/investing countries which not only examines the technology sourcing versus technology exploitation hypotheses for the sample overall, but does so separately for those sectors and countries which the conceptual literature identifies as being most likely to exhibit these contrasting forms of investing behaviour (Patel and Vega, 1999). The next section provides an overview of the literature on technology sourcing and related issues. This is followed by the development of the empirical model, and a discussion of the results for both outward and inward FDI between the United States and seven major OECD countries. The paper concludes that, while there is evidence that FDI tends to be attracted to research-intensive sectors, there is relatively little support for the technology sourcing hypothesis for FDI flows between the United States and other major OECD countries.

\section{Evidence on Technology Sourcing}

As noted by Neven and Siotis (1996), there has been considerable concern by some countries that domestic technology can be "tapped into" by foreign investors. This can be the case when foreign firms, operating in home countries where the technological base is relatively weak in a chosen sector, choose to invest in leading centres of research and development excellence, for example by developing collaborations between local R\&D laboratories and universities. Much of the work in this area has therefore tended to concentrate on the internationalisation of $R \& D$ and related activities. 
Kuemmerle (1999a) distinguishes between 'home-base exploiting' (HBE) FDI and 'home-base augmenting' (HBA) FDI. The former is undertaken in order to exploit firm-specific advantages abroad, while the latter is FDI undertaken to access unique resources and capture externalities created locally. His subsequent empirical work (Kuemmerle 1999b) finds evidence that that HBE and HBA research sites are subject to different locational determinants. Patel and Vega (1999) push this conceptual model further. They suggest a 'revealed technological advantage' (RTA) index analogous to indices of revealed comparative advantage in trade, and suggests four categories of international technological activity:

Type 1: Home $\mathrm{RTA}<1$ and Host $\mathrm{RTA}>1$; weak home, strong host i.e. true technological sourcing.

Type 2: Home RTA $>1$ and Host RTA $<1$; strong home, weak host i.e. closest to the traditional ownership advantage idea from the Eclectic Paradigm and similar to Kuemmerle’s ‘home-base exploiting' (HBE).

Type 3: Home RTA $>1$ and Host RTA $>1$; strong home and host i.e. roughly Kuemmerle's 'home-base augmenting' (HBA) coupled with 'strategic asset seeking behaviour' (Dunning and Narula 1995).

Type 4: Home RTA $<1$ and Host RTA $<1$; both home and host weak; result of e.g. mergers where the FDI motive is unrelated to technology.

Although there has been no direct testing of these categories, there is considerable survey-based evidence on technology sourcing as a motive for internationalising R\&D. Using survey evidence for Swedish chemical and engineering industries, Håkanson and Nobel (1993) find relatively limited evidence of technology sourcing; of a total of 172 Swedish research laboratories set up abroad, only 13 were set up with the sole intention of sourcing foreign technology. However, Gassmann and von Zedtwitz (1999) find strong evidence that when foreign technology development becomes too significant to ignore companies establish 'listening posts' in areas of technological expertise around the World. In a study of patent citations in the US semiconductor industry, Almeida (1996) finds that foreign subsidiaries make more use of sector and geographically specific knowledge than do domestic firms, and concludes that Korean and European subsidiaries in particular use 'knowledge sourcing' from US firms to upgrade their technological ability in areas in which they 
are relatively weak. An analysis of foreign $R \& D$ direct investment in the United States by Serapio and Dalton (1999) concludes that the nature of such investment is changing, with more emphasis on gaining direct access to American technology and expertise, especially in biotechnology and electronics. They also conclude that foreign firms are increasingly investing in $R \& D$ sites in the United States to access technologies which are complementary to those of the investing firms. Pearce (1999) comes to broadly similar conclusions from a survey of multinational corporations' production and laboratory facilities in the UK. Companies which previously exerted rather tight control over their R\&D sites are now granting more autonomy and empowerment to R\&D laboratories situated abroad. It appears that, whereas in the 1970s and early 1980s organisations saw establishing R\&D outlets abroad as little more than adapting products to local markets as hypothesised by the product life cycle hypothesis, during the 1990s organisations began to take a more decentralised approach to R\&D (Niosi 1999). The emphasis tends to be on an integrated strategy with co-ordination of R\&D resources across national boundaries.

There is evidence, however, that investment abroad is not merely restricted to firms operating in areas of domestic weakness. For example, Cantwell and Janne (1999) examine European firm patents granted in the United States from 1969 to 1995 and find evidence that leading multinationals operating in major European centres in their own activity tend to carry out technological activity abroad which is relatively differentiated from their domestic technological strengths. Conversely, firms from lower order centres tend to locate research in their own domestic fields of technological strength, extending the depth of their established lines of activity in the most important centre in the locational hierarchy of their industry. This work, and that of Serapio and Dalton (1999) reviewed above, suggests that it is mistaken to imagine that 'technology sourcing' always involves technologically weak countries accessing the technology of those which are technologically strong; technology sourcing may occur where both parties are absolutely strong in technology, but where one is rather stronger than the other i.e. the 'Type 3' investment of Patel and Vega (1999). Indirect support for this contention comes from Chen and Chen's (1998) work on network linkages. They find that Taiwanese firms use strategic network connections to gain access to strategic assets in foreign countries, especially the United States. This strategic linkage approach explicitly views FDI as an attempt to 
acquire knowledge that reinforces the strengths of the investor, or complements the investor's weaknesses.

Recent research on domestic $R \& D$ appears to lend some indirect support for the technology sourcing hypothesis. Driffield and Munday (2000) study inward investment into the United Kingdom between 1984 and 1992, and find evidence that R\&D intensity in the relevant UK sector has a significantly positive effect on inward FDI. Intriguingly, Driffield and Munday explain this as evidence of the importance of proprietary knowledge as a source of ownership advantage, rather than as evidence of technology sourcing. Vannoni (1999) examines numbers of Italian firm entries and exits into the EU and finds that $R \& D$ expenditures in host country industries have a significant impact on Italian firm entry abroad. Barriers to entry with regards to public procurement policies, distance from Italy, and unit labour costs in host countries were also found to be important.

Only a handful of studies have attempted direct econometric analysis on the specific issue of technology sourcing. Kogut and Chang (1991) examine the entry of Japanese firms into specific US sectors from 1976 to 1987, and use an R\&D difference variable in an attempt to account for technology sourcing as a potential motive for Japanese entry into US markets. The intuition is that should the US sector in question experience a higher R\&D intensity relative to the Japanese sector, then this would encourage Japanese firms who wish to source US technology to set up in the United States ${ }^{1}$. The authors found that US R\&D intensities and innovation frequencies were positively associated with Japanese entry, but the coefficients for these variables were insignificant. Barriers to entry and especially the tariff-jumping motive were found to be more important, providing further evidence that Japanese investment abroad tends to be particularly sensitive to trade barriers. Only in the case of joint ventures did Kogut and Chang find evidence that US-Japanese R\&D differentials encouraged inward investment. In a similar vein Neven and Siotis (1996) examined both Japanese and US investment into the EC together with intra EC FDI flows. Using Kogut and Chang's R\&D difference variable to examine the possibility of technological sourcing, Neven and Siotis examine actual FDI flows rather than the propensity for foreign entry. Although there is some evidence that technology 
sourcing is a consideration for both Japanese and US firms, the evidence tends to be rather weak, with the R\&D differential variables having coefficients significant only at the $10 \%$ level. Stronger evidence was found that US investments into the EC tended to be more motivated by tariff jumping considerations together with growth in European markets.

Finally, using similar R\&D sum and differential measures to Kogut and Chang and to Neven and Siotis, Beladi et al (1999) find no evidence of technology sourcing by major investing countries into the United States over the periods 1980-86 and 198793, and conclude that traditional firm-specific advantages are more likely to be the motivation for FDI. However, like the previous studies, Beladi et al do find evidence that FDI is more likely to occur in industries where overall $R \& D$ expenditures are high. The message from these empirical studies appears to be that domestic investment in R\&D can indeed be associated with relatively high levels of FDI, but that there is relatively weak (at best) evidence for outright technology sourcing by inward investing firms.

This suggests something of a dichotomy between two strands of the literature. On the one hand, the literature on globalization of R\&D and network linkages appears to provide evidence, albeit of an anecdotal and survey nature, of increasing internationalization of research related FDI, at least partly motivated by a desire to keep up with or access leading edge technologies internationally. On the other hand, the econometric evidence on foreign entry and overall FDI flows suggests at best weak evidence for the existence of technology sourcing on a systematic scale. However, it may not be surprising that the technology sourcing motive fails to show strongly in previous analysis of aggregate FDI flows, as this effect would tend to be 'washed out' by the myriad other influences on overall FDI. This suggests that there is merit in examining not simply aggregate FDI flows, but in concentrating the analysis on those sectors and countries where, conceptually, there are grounds for believing the technology sourcing and technology exploiting effects are most likely to be clearly differentiated.

${ }^{1} \mathrm{R} \& \mathrm{D}$ intensity is measured as a ratio of total R\&D expenditures divided by sales 
The present research attempts to do this by performing a panel analysis of manufacturing FDI flows between the United States and its major recipient/investing countries which not only examines the technology sourcing hypothesis for the sample overall, but does so separately for the 'Types' of investment identified in the classification of Patel and Vega (1999). This serves two purposes. First, it offers further evidence on the existence or otherwise of technology-sourcing FDI into and out of the world's principal investing and recipient nation for a longer and more recent time period than previous research; previous studies have examined technology sourcing into or from the United States, but not both. Secondly, it permits an empirical test of the categories suggested by Patel and Vega: a priori one would expect to find the strongest evidence of technology sourcing in their Type 1 category (technologically weak home country and strong host country) and weaker evidence of technology sourcing in the other categories, with the strongest evidence for the technology exploiting hypothesis being found in the Type 2 category (technologically strong home country and relatively weak host).

\section{Empirical Model}

Empirical testing of the technology sourcing hypothesis should be placed within a plausible model of FDI. One model, which has been widely tested, suggests that the optimal stock of foreign capital for any firm $\left(\mathrm{K}^{*}\right)$ depends principally on the scale of demand in the recipient country (the 'market size' hypothesis), and on relative factor costs in the capital exporting and recipient countries, i.e.

$$
\mathrm{K}^{*}=\mathrm{K}\left[\mathrm{X}_{\mathrm{f}},\left(\mathrm{c}_{\mathrm{f}}-\mathrm{c}_{\mathrm{d}}\right)\right]
$$

where $X_{f}$ is demand in the host ('foreign') country and $c_{f}-c_{d}$ is the unit cost differential between production in the host and home ('domestic') country. However, in any given period, actual and desired foreign capital stocks are unlikely to be equal as a result of adjustment costs and operating lags, such as delays in finding suitable overseas investments, delivery lags etc. (Barrell and Pain, 1996). Flows of foreign direct investment (FDI) will therefore be a lagged function of the difference between actual and desired capital stocks in previous periods, in addition to demand and factor cost issues. This can be considered as a partial adjustment model of the form: 


$$
\mathrm{I}_{\mathrm{t}}=\gamma\left(\mathrm{K}_{\mathrm{t}}^{*}-\mathrm{K}_{\mathrm{t}-1}\right)+\delta \mathrm{K}_{\mathrm{t}-1}
$$

where $I_{t}$ is the flow of FDI in year $t, K_{t-1}$ is the lagged value of actual foreign capital stock, and $\gamma$ is a distributed lag function. This can be rewritten:

$$
\mathrm{I}_{\mathrm{t}}=\gamma \mathrm{K}^{*}+(\delta-\gamma) \mathrm{K}_{\mathrm{t}-1}
$$

Thus the flow of FDI depends both on the determinants of the optimal capital stock derived from equation (1), and on the lagged value of actual foreign capital stock

Empirical testing takes the general form:

$$
\mathrm{I}_{\mathrm{t}}=\alpha_{0}+\alpha_{1} \mathrm{X}_{\mathrm{t}}+\alpha_{2}\left(\mathrm{c}_{\mathrm{f}}-\mathrm{c}_{\mathrm{d}}\right)_{\mathrm{t}}+\alpha_{3} \mathrm{~K}_{\mathrm{t}-1}+\varepsilon_{\mathrm{t}}
$$

Specifications of this sort have been empirically tested for direct investment flows into the United Kingdom (Pain, 1993), South East Asia (Lucas, 1993), Spain (BajoRubio and Sosvilla-Rivero, 1994), Mexico (Love and Lage-Hidalgo, 2000) and for outward direct investment from the United States (Barrell and Pain, 1996). In the estimations discussed below, an augmented version of this basic model is tested on panel data to distinguish between the technology sourcing and technology exploiting hypotheses.

\section{Data}

The data involve a panel of sectoral level FDI flows and their determinants over the period 1981-95 both from the United States to its major recipient countries, and from these countries into the United States. This permits testing of the technology sourcing and technology exploiting hypotheses both from and to the United States. For outward FDI (i.e. investment flows from the United States) consistent data are available at the NACE/ISIC 2-digit level for seven manufacturing sectors (food, drink and tobacco; chemicals; metal products; non-electrical equipment; electrical and electronic goods; transport equipment; and other manufacturing) for seven major recipient countries (Canada, France, Germany, Italy, Netherlands, Japan and UK). 
For inward FDI flows (i.e. investment flows into the United States) the same seven major investing countries are included in the panel data for five sectors (food and kindred products; chemicals; primary and fabricated metals; machinery; and other manufacturing). These countries are among the major FDI investing and recipient economies, collectively accounting for $82 \%$ of direct investment outflows and $67 \%$ of inflows within the OECD during the 1990s (Table 1).

The dependent variable is $\mathrm{FDI}_{\mathrm{it}}$, the flow of direct investment from home to host country sector per time period, expressed per unit of output in the host country sector. Expressing the dependent variable in this way removes the need for a separate independent variable to proxy the host's market size, and is consistent with previous research in the area (Neven and Siotis 1996; Beladi et al 1999). FDI $_{\mathrm{it}}$ includes equity capital, reinvested earnings and debt flows between parent and affiliates, which are the three elements of FDI agreed for reporting in the IMF's Balance of Payments Yearbook (Barrell and Pain 1997, p. 64). Unit cost differentials are proxied by the real unit labour cost differential between host and home country sectors $\left(\mathrm{ULCDIF}_{\mathrm{it}}\right)^{2} . \mathrm{K}_{\mathrm{it}-1}$ is the real value of FDI stock in the host country's sector from the relevant home country, lagged one year.

The specification suggested by equation (4) concentrates exclusively on the 'locational' determinants of FDI flows. To test for the technology sourcing and firmspecific 'ownership' effects several extensions are made to the basic model. R\&D intensity $\left(\mathrm{RDI}_{\mathrm{it}}\right)$, defined as $\mathrm{R} \& \mathrm{D}$ expenditure divided by output in the host and home countries sectors, is used to differentiate between the technology sourcing and technology exploiting incentives for FDI: a positive association between host country R\&D intensity and FDI flows suggests technology sourcing as a motive, while a positive association between home country R\&D intensity and FDI flows points to the predominance of technology exploiting motive. However, Kogut and Chang (1991), Neven and Siotis (1996) and Beladi et al (1999) observe that sectoral R\&D intensities across countries tend to be highly correlated, and instead employ the sum and difference of R\&D intensities between host and home countries which tend to

${ }^{2}$ Cost of capital differentials are not include in the estimation because they tend to display little variation by sector and because the empirical evidence on FDI flows suggests they tend to have an insignificant effect, unlike relative unit labour costs (Bajo-Rubio and Sosvilla-Rivero 1994; Love and Lage-Hidalgo, 2000). 


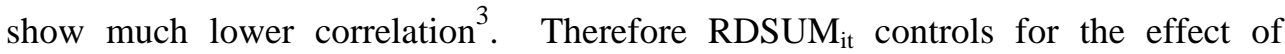
technology as a transferable asset in FDI, while RDDIF (host minus home) tests for the motivational influence: a positive coefficient on RDDIF suggests the technology sourcing motive, while a negative coefficient indicates technology exploitation. Measures are also included to allow for the possible impact on FDI of tariff and nontariff barriers at the industry level, to account for the possible 'tariff-jumping' motive and to allow for the move towards increased reliance on non-tariff trade bariers during the period in question. $\mathrm{TAR}_{\mathrm{i}}$ is the production-weighted average of ad valorem tariff rates per sector in the host country, and $\mathrm{NTB}_{\mathrm{i}}$ is a frequency ratio indicating the percentage of national tariff lines which are affected by major non-tariff barriers such as quotas and voluntary export restraints. Full details of the data sources can be found in the data appendix.

The estimating equation is thus:

$$
\begin{aligned}
\mathrm{FDI}_{\mathrm{it}}=\beta_{0}+ & \beta_{1} \mathrm{RDSUM}_{\mathrm{it}}+\beta_{2} \mathrm{RDDIF}_{\mathrm{it}}+\beta_{3} \mathrm{ULCDIF}_{\mathrm{it}}+\beta_{4} \mathrm{TAR}_{\mathrm{it}}+\beta_{4} \mathrm{NTB}_{\mathrm{it}} \\
& +\beta_{4} \mathrm{~K}_{\mathrm{it}-1}+\mu_{\mathrm{it}}
\end{aligned}
$$

where $\mu_{\mathrm{it}}=\alpha_{\mathrm{i}}+\varpi_{\mathrm{t}}+v_{\mathrm{it}}$. This is the standard 'random effects' model outlined in Baltagi (1995). ${ }^{4}$

\section{Results}

\section{a) Outward FDI}

The results of panel data estimation for outward US direct investment to the seven recipient countries are considered first. The procedure involves estimating equation (5) first for overall FDI flows from the United States, and then separately for the different investment 'Types' identified in the Patel and Vega taxonomy.

For the overall estimation, missing data reduced the 735 possible observations to 704 actual observations. These results are given in Table 2. Column (a) shows the OLS

\footnotetext{
${ }^{3}$ This is true also of the present data set. For example, in the inward FDI sample the correlation coefficient between US and foreign RDI is 0.46 , while that between RDSUM and RDDIF is 0.24 .

${ }^{4}$ The restriction of fixed versus random effects is formally tested in the results section below.
} 
regression results, which simply pools together all observations. The OLS results show highly significant coefficients for RDSUM and RDDIF, apparently indicating that FDI outflows from the United States are more likely in R\&D intensive sectors, and that technology sourcing is an important motivation for these flows. However, these results are highly misleading as they fail to account for any sector and time effects present in the panel data. Full panel estimation indicated that a one-way fixed effects model was appropriate, ${ }^{5}$ as indicated by the Hausman test results in Table 2. The fixed-effects results (column b) indicate that the apparent technology-sourcing effect is removed once the influence of country/sector fixed effects are properly allowed for; the only remaining variable with a significant coefficient is $\mathrm{K}_{\mathrm{t}-1}$, which has the predicted sign. All other variables have highly insignificant coefficients. The model has an adjusted $\mathrm{R}^{2}$ of 0.23 . The coefficients on TAR and NTB were insignificant for these and all other estimations, and are dropped from the subsequent analysis.

The coefficients on the fixed effects dummy variables (not shown) suggest that these are essentially country rather than sectoral effects. To illustrate the importance of these country effects, an estimation was carried out which stratifies the panel only by sector and includes country dummies (column c). In this case a Hausman test indicated that a random effects model was appropriate ${ }^{6}$. In this estimation RDSUM again has a significantly positive coefficient, but that on RDDIF is negative but insignificant. ULCDIF has the anticipated negative coefficient which is significant at $5 \%$, and the country dummies for Canada, the Netherlands and the UK have statistically positive coefficients. Thus for overall outward FDI flows form the United States, while there is evidence that FDI does tend to flow between relatively $\mathrm{R} \& \mathrm{D}$ intensive sectors, there is little support for outright technology sourcing.

As suggested earlier, however, technology sourcing may be an activity restricted to particular sectors or countries, and its effects may thus be masked in consideration of overall sectoral FDI flows. The next stage is therefore to test whether the hypothetical categories developed by Patel and Vega (1999) have any influence on the technology sourcing effect. As indicated in the literature review, Patel and Vega

\footnotetext{
${ }^{5}$ This suggests a lack of significant time period effects for the outward FDI flows.

${ }^{6}$ The results of the fixed-effects version were not qualitatively different.
} 
suggest a 'revealed technological advantage' (RTA) index analogous to indices of revealed comparative advantage in trade ${ }^{7}$, defined here as country i's proportion of OECD R\&D expenditure in sector $\mathrm{j}$ divided by country i's proportion of total OECD R\&D expenditure. Thus where OECD takes the subscript o:

$$
R T A=\frac{R \& D_{i j} / R \& D_{o j}}{\sum_{j=1}^{n} R \& D_{i j} / \sum_{j=1}^{n} R \& D_{o j}}
$$

In the Patel and Vega taxonomy, 'Type 1' investment is where $\mathrm{RTA}_{\text {home }}<1$ and $\mathrm{RTA}_{\text {host }}>1$ i.e. the home country is technologically weak and the host technologically strong. This is a priori the most likely scenario for technology sourcing to occur, and accounts for $43 \%$ of the (outward) observations in the panel. 'Type 2' investment occurs where the home is technologically strong and the host relatively weak, closer to the traditional idea of a strong multinational firm exploiting its technology abroad (29\% of the observations in the outward panel). 'Type 3' investment is where both home and host are relatively technologically strong ( $8 \%$ of the outward panel), and 'Type 4' where both home and host country are relatively weak (20\% of the outward panel).

Patel and Vega develop this principally as a taxonomy with no empirical testing as to effects on FDI flows. Clearly this approach puts a lot of stress on the arbitrary cut-off point of unity for the indices. Thus a home country with an RTA of 1.01 investing in a host with an RTA of 5 would be regarded as engaging in Type 3 'home-base augmenting' investment (because both values are above unity) despite the massively greater technological intensity of the host economy But it is possible that technology sourcing could be the motive here because of the substantial differences in relative 'technological advantage'. This suggests that, in interpreting probable motives for FDI, empirical research has to take account not merely of the RTA values, but of the differences in technological intensities between home and host economies. This is, of

\footnotetext{
${ }^{7}$ This type of index was developed initially by Soete (1987) and used subsequently by Cantwell (1989). Almeida (1996) also makes use of a similar index. Soete's RTA index uses patents rather than R\&D expenditure, and is thus an output rather than an input measure. However, Soete (1987) also shows that input and output measures of technological activity are strongly correlated.
} 
course, the role played by the RDDIF variable, and shows the advantage of combining the econometric analysis of the technology sourcing literature with the taxonomy of Patel and Vega. ${ }^{8}$ For present purposes, the principal concern is with the possible different motivational implications of Type 1 and Type 2 investment, where the technology sourcing and technology exploiting motives should be most clearly distinguished. Separate panel estimations of equation (5) are therefore undertaken for observations falling into these two categories.

Columns (d) and (e) respectively of Table 2 show the results for these two types. In neither case is there any support for the technology sourcing hypothesis. The fixedeffects results for Type 1 observations (column d) show all variables with coefficients of the expected sign, but all insignificant: only the country/sector fixed effects show any significant coefficients (not shown). In the case of Type 2 investment (column e), the R\&D variables have highly insignificant coefficients; ULCDIF and $\mathrm{K}_{\mathrm{t}-1}$ have significant coefficients, but the former has a counterintuitive sign. Ideally, a separate estimation should also be carried out for Type 3 observations in order to test whether, for example, technological sourcing is still a viable motive even for where both home and host are relatively technologically strong. However, the limited number of observations in this category (58) precludes this in a panel which includes 49 fixed-effects dummy variables.

Overall, these results suggest there is little support for the technology sourcing hypothesis with respect to FDI flows between the United States and its major recipient nations, even for those sectors in which such an effect might be most likely. This contrasts with the results of Neven and Siotis (1996) who performed a similar analysis $^{9}$ on FDI flows between the United States and four EU countries over the period 1984-89 and found some (weak) evidence to support the technology sourcing hypothesis. The difference between the present results and those of Neven and Siotis may be partly due to the longer time period and more extensive group of countries which employed here, but is more probably a result of the use of full panel

\footnotetext{
${ }^{8}$ The variables used to measure $\mathrm{R} \& \mathrm{D}$ intensity $\left(\mathrm{RDI}_{\mathrm{it}}\right)$ and revealed technological advantage $\left(\mathrm{RTA}_{\mathrm{it}}\right)$ are not highly correlated. For the outward FDI sample, the correlation coefficients between $\mathrm{RDI}_{\mathrm{it}}$ and $\mathrm{RTA}_{\mathrm{it}}$ are 0.123 for the host countries and 0.368 for the United States, while for the inward FDI sample the equivalent correlation coefficients are 0.076 for the home countries and 0.385 for the United States.

${ }^{9}$ However, Neven and Siotis did not attempt to break their sample into Type 1 and Type 2 categories.
} 
estimation which Neven and Siotis were unable to undertake. In addition, Neven and Siotis did not allow for the unit labour cost or lagged stock effects included in the present model.

\section{b) Inward FDI}

The next stage is to test for the existence of technology sourcing in FDI into the United States from the same seven major investing countries. In most cases a twoway panel estimation was conducted on inward FDI flows, because of the existence of significant time period effects ${ }^{10}$. With one exception, fixed effects estimation was found to be appropriate. Table 3 shows the results of the basic model on 473 available observations ${ }^{11}$. As with the outward FDI estimations, the tariff and nontariff barrier variables consistently had insignificant coefficients and were dropped from the analysis. Table 3 shows two versions of this inward model; in the first, the unit cost differential is as before (column a), and the alternative is RULC $\mathrm{it}_{\mathrm{it}}$, a measure of the home countries' unit labour costs relative to the OECD sectoral average (column b). The results are somewhat stronger than for the outward FDI estimation. The positive and significant coefficients on RDSUM suggest that R\&D intensive sectors are more likely to attract inward investment into the United States. However, in both estimations the coefficient on RDDIF is negative, and in one estimation it is significant at the $10 \%$ level, suggesting that for inward FDI flows into these US sectors, the technology exploiting motive predominates. ULCDIF/RULC and $\mathrm{K}_{\mathrm{t}-1}$ have coefficients with the correct sign, but are statistically insignificant. The models have an adjusted $\mathrm{R}^{2}$ of 0.37 , considerably higher than for the outward FDI estimations.

As with the outward estimations, separate panel estimations can be performed for Type 1 and Type 2 investments ${ }^{12}$. The Type 1 estimation, which accounts for $20 \%$ of the total observations, shows the first suggestion of support for the technology souring hypothesis, (Table 2 column c). Both RDSUM and RDDIF have

\footnotetext{
${ }^{10}$ These relate mainly to the period 1987-89 when there was an upsurge in inward FDI to the United States. The only exception to this was the model for Type 1 inward investment, which showed no evidence of time effects.

${ }^{11}$ Missing data reduced the observations from a possible 525.
} 
significantly positive coefficients, although ULCDIF remains insignificant. However, this is a less pervasive effect than it might first appear. For inward investment, Type 1 observations are restricted to the 'other manufacturing' sector, a catchall which includes a number of relatively low-technology industries ${ }^{13}$. The results for Type 2 investment (column d) shows broadly what would be expected from Patel and Vega's taxonomy. The significantly positive coefficient on RDSUM continues to indicate that FDI flows are attracted to relatively high R\&D sectors, while the negative (but marginally insignificant) coefficient on RDDIF is suggestive of a technology exploiting rather than technology sourcing motive, in line with the expected outcome for this category of investment. ULCDIF and $\mathrm{K}_{\mathrm{t}-1}$ have coefficients with the anticipated signs, the latter statistically significant.

These results are very much in keeping with those of Beladi et al (1999) who found strong and consistent evidence that direct investment into the United states is attracted to relatively $R \& D$ intensive manufacturing sectors: the consistently significant and positive coefficients on RDSUM support this conclusion. And, like Beladi et al, I find no support for the technology sourcing hypothesis on overall FDI into the United States, and some support for the hypothesis that companies investing in the United States do so to exploit their existing technology, rather than access US technology. However, there is some hint of technology sourcing in the 'other manufacturing' sector in which the United States has a consistent revealed technological advantage over its other OECD counterparts.

\section{Conclusions}

The purpose of this paper is to add to the developing literature on technology sourcing versus technology exploitation as a motivation for FDI. Unlike previous research I have been able to undertake panel analysis of manufacturing FDI flows in both directions between the United States and its major investing/recipient nations.

\footnotetext{
${ }^{12}$ As with the outward FDI data, the low number of Type 3 observations (10) precluded separate estimation for this category.
} 
In addition, I performed separate estimations for clusters of FDI observations which the conceptual literature suggests are most likely to exhibit different technologyrelated investing behaviour. As far as I am aware, this is the first empirical use of Patel and Vega's (1999) taxonomy.

In common with much of the previous literature, there is consistent evidence that FDI into the United States is attracted to relatively R\&D-intensive sectors: this effect is also present, but less pronounced, for FDI flows from the United States. However, the econometric analysis provides very little support for the technology sourcing hypothesis. There is no evidence of technology sourcing in outward US direct investment, even in the sectors in which the United States has a relative technological disadvantage compared to the recipient countries. In the case of inward FDI this result is even more pronounced. Not only is there almost no support for technology sourcing, but the evidence points towards technology exploitation by foreign multinationals operating in the United States: the possible exception to this is the 'other manufacturing' sector, in which the United States has a consistent revealed technological advantage with the relevant investing nations, and where there is a hint of a technology sourcing effect.

There is little in these results to support the concerns expressed in Kogut and Chang (1991) and Neven and Siotis (1996) about the possibility of widespread technology sourcing by foreign investors among OECD countries. The results indicate that simply because $R \& D$ intensive sectors attract a great deal of direct investment, this does not necessarily indicate that this investment is being undertaken to access the technology of foreign hosts. Indeed, these results, like those of Beladi et al (1999), suggest that the technological 'ownership' advantage is still a powerful determinant of FDI flows, even in relatively R\&D intensive sectors. The fact that there is little evidence for technology sourcing in FDI into the United States is perhaps the most striking finding. This may be connected to the relatively high proportion of federally funded R\&D among the research-intensive sectors of the United States. Incoming foreign companies may take the opinion that there is little scope for spillover learning effects from such $R \& D$, and the sectors in which there is some support for the

\footnotetext{
${ }^{13}$ For inward investment this category includes textiles; paper, printing and publishing; rubber and plastics; non-metallic mineral products; and transportation equipment.
} 
technology sourcing hypothesis tend to be relatively non-research intensive and lacking in federally funded R\&D. More prosaically, however, this finding may simply reflect the fact that the size of the American economy is an attractive motivational influence for foreign investors, regardless of any technological advantage to be gained from locating in the United States.

I recognise, however, that these findings do not suggest that individual acts of technology sourcing never occur. Clearly estimation of this kind can do no more than look for patterns in the overall level of FDI, and can only be a complement to detailed survey-based analysis of the behaviour of multinational enterprises. For the same reason the present findings need not be viewed as incompatible with the literature on the internationalization of $\mathrm{R} \& \mathrm{D}$ and the establishing of facilities designed in part to absorb spillovers through proximity to leading edge technological establishments. Such behaviour could conceivably be the precursor to more widespread subsequent FDI flows, but the results detailed above suggest that direct investment of this type is still a relatively minor motivational element within overall FDI flows. 


\section{Data Appendix}

\begin{tabular}{|c|c|c|}
\hline Variable & Definition & Source \\
\hline FDI & $\begin{array}{l}\text { Flows of direct investment from/to the } \\
\text { United States from the relevant countries, } \\
\text { divided by host country sectoral output. } \\
\text { FDI flows comprise equity capital + } \\
\text { reinvested earnings + intercompany debt } \\
\text { flows. }\end{array}$ & $\begin{array}{l}\text { US Bureau of Economic } \\
\text { Analysis. }\end{array}$ \\
\hline RDI & $\begin{array}{l}\text { R\&D intensity i.e. } R \& D \text { expenditure } \\
\text { divided by output. }\end{array}$ & $\begin{array}{l}\text { OECD ANBERD/ANRSE } \\
\text { database (R\&D expenditure) } \\
\text { and OECD STAN database } \\
\text { (production) }\end{array}$ \\
\hline RDSUM & Sum of RDI for host and home countries. & As above \\
\hline RDDIF & $\begin{array}{l}\text { Difference between RDI for host and home } \\
\text { countries (host minus home). }\end{array}$ & As above \\
\hline RTA & $\begin{array}{l}\text { Index of revealed technological advantage } \\
\text { i.e. country i's proportion of OECD R\&D } \\
\text { expenditure in sector j divided by country } \\
\text { i’s proportion of total OECD R\&D } \\
\text { expenditure. }\end{array}$ & $\begin{array}{l}\text { OECD ANBERD/ANRSE } \\
\text { database }\end{array}$ \\
\hline ULCDIF & $\begin{array}{l}\text { Difference between unit labour costs for } \\
\text { host and home countries (host minus } \\
\text { home). }\end{array}$ & OECD \\
\hline RULC & $\begin{array}{l}\text { Relative unit labour costs (relative to } \\
\text { OECD sectoral average) }\end{array}$ & $\begin{array}{l}\text { OECD Main Industrial } \\
\text { Indicators database }\end{array}$ \\
\hline TAR & $\begin{array}{l}\text { Production-weighted average of } a d \\
\text { valorem tariff rates per sector in the host } \\
\text { country. }\end{array}$ & $\begin{array}{l}\text { OECD Indicators of Tariff and } \\
\text { Non-Tariff Barriers }\end{array}$ \\
\hline NTB & $\begin{array}{l}\text { Frequency ratio indicating the percentage } \\
\text { of national tariff lines which are affected by } \\
\text { major non-tariff barriers such as quotas and } \\
\text { voluntary export restraints. }\end{array}$ & $\begin{array}{l}\text { OECD Indicators of Tariff and } \\
\text { Non-Tariff Barriers }\end{array}$ \\
\hline $\mathrm{K}_{\mathrm{t}-1}$ & Real stock of FDI, lagged one year. & $\begin{array}{l}\text { US Bureau of Economic } \\
\text { Analysis }\end{array}$ \\
\hline
\end{tabular}


Table 1: Cumulative FDI flows involving OECD countries, 1990-1998 (\$ million) Source: Financial Market Trends, OECD, June 1999

\begin{tabular}{|c|c|c|c|}
\hline Inflows & & Outflows & \\
\hline United States & 605052 & United States & 662652 \\
\hline United Kingdom & 240513 & United Kingdom & 364733 \\
\hline France & 178323 & Germany & 318640 \\
\hline Belgium-Luxembourg & 105859 & France & 257407 \\
\hline Netherlands & 101028 & Japan & 227984 \\
\hline Spain & 84039 & Netherlands & 180864 \\
\hline Mexico & 68576 & Canada & 93565 \\
\hline Sweden & 67798 & Switzerland & 83657 \\
\hline Canada & 66888 & Sweden & 80010 \\
\hline Germany & 60260 & Belgium- Luxembourg & 79540 \\
\hline Australia & 55603 & Italy & 71624 \\
\hline Italy & 31278 & Spain & 50984 \\
\hline Greece & 26823 & Finland & 37736 \\
\hline Denmark & 24456 & Australia & 27636 \\
\hline Poland & 22909 & Korea & 24931 \\
\hline Switzerland & 22073 & Denmark & 24657 \\
\hline Norway & 19709 & Norway & 22730 \\
\hline New Zealand & 19523 & Austria & 15516 \\
\hline Austria & 18875 & Portugal & 8029 \\
\hline Finland & 18794 & New Zealand & 4079 \\
\hline Hungary & 17193 & Turkey & 1442 \\
\hline Portugal & 16091 & Hungary & 1012 \\
\hline Korea & 15582 & Czech Republic & 500 \\
\hline Japan & 13631 & Poland & 363 \\
\hline OECD & 1928899 & OECD & 2640600 \\
\hline
\end{tabular}


Table 2. Panel Regression Analysis: Outward FDI
(a)
(b)
(c)
(d)
(e)

\begin{tabular}{|c|c|c|c|c|c|}
\hline Constant & $\begin{array}{l}1.139 \\
(0.803)\end{array}$ & --- & $\begin{array}{l}-0.889 \\
(1.163)\end{array}$ & --- & $\begin{array}{l}8.545 * * \\
(4.320)\end{array}$ \\
\hline RDSUM & $\begin{array}{l}25.395 * * * \\
(5.692)\end{array}$ & $\begin{array}{l}15.898 \\
(17.272)\end{array}$ & $\begin{array}{l}22.462 * * \\
(9.822)\end{array}$ & $\begin{array}{l}27.056 \\
(20.156)\end{array}$ & $\begin{array}{l}-27.049 \\
(47.891)\end{array}$ \\
\hline RDDIF & $\begin{array}{l}35.655^{* * *} \\
(8.315)\end{array}$ & $\begin{array}{l}-7.585 \\
(23.125)\end{array}$ & $\begin{array}{l}9.171 \\
(12.453)\end{array}$ & $\begin{array}{l}3.346 \\
(27.137)\end{array}$ & $\begin{array}{l}28.316 \\
(59.440)\end{array}$ \\
\hline ULCDIF & $\begin{array}{l}2.131 * * * \\
(0.811)\end{array}$ & $\begin{array}{l}-1.050 \\
(1.731)\end{array}$ & $\begin{array}{l}-2.506^{* *} \\
(1.216)\end{array}$ & $\begin{array}{l}-3.809 \\
(2.569)\end{array}$ & $\begin{array}{l}6.944 * \\
(4.074)\end{array}$ \\
\hline $\mathrm{K}_{\mathrm{t}-1}\left(10^{-3}\right)$ & $\begin{array}{l}0.582 * * * \\
(0.145)\end{array}$ & $\begin{array}{l}-0.629 * * \\
(0.317)\end{array}$ & $\begin{array}{l}-0.093 \\
(0.198)\end{array}$ & $\begin{array}{l}-0.133 \\
(0.419)\end{array}$ & $\begin{array}{l}-1.131 * * \\
(0.692)\end{array}$ \\
\hline TAR & $\begin{array}{l}-0.015 \\
(0.015)\end{array}$ & $\begin{array}{l}-0.101 \\
(0.208)\end{array}$ & --- & --- & --- \\
\hline NTB & $\begin{array}{l}-0.059 \\
(0.045)\end{array}$ & $\begin{array}{l}-0.043 \\
(0.129)\end{array}$ & --- & --- & --- \\
\hline Canada & --- & --- & $\begin{array}{l}8.720 * * * \\
(1.305)\end{array}$ & --- & --- \\
\hline France & --- & --- & $\begin{array}{l}0.314 \\
(0.784)\end{array}$ & --- & --- \\
\hline Germany & --- & --- & $\begin{array}{l}0.609 \\
(0.851)\end{array}$ & --- & --- \\
\hline Italy & --- & --- & $\begin{array}{l}0.214 \\
(0.778)\end{array}$ & --- & --- \\
\hline Netherlands & --- & --- & $\begin{array}{l}1.791 * * \\
(0.798)\end{array}$ & --- & --- \\
\hline UK & --- & --- & $\begin{array}{l}4.567 * * * \\
(1.107)\end{array}$ & --- & --- \\
\hline Adjusted $\mathrm{R}^{2}$ & 0.125 & 0.232 & 0.209 & 0.265 & 0.144 \\
\hline No. Observations & 704 & 704 & 704 & 301 & 205 \\
\hline $\begin{array}{l}\text { Fixed vs. random } \\
\text { effects: } \chi^{2} \text { [d.f.] }\end{array}$ & --- & $\begin{array}{l}24.34 \\
(0.00)[6 \mathrm{df}]\end{array}$ & $\begin{array}{l}1.69 \\
(0.99)[10 \mathrm{df}]\end{array}$ & $\begin{array}{l}14.78 \\
(0.00)[4 \mathrm{df}]\end{array}$ & $\begin{array}{c}7.72 \\
(0.10)[4 \mathrm{df}]\end{array}$ \\
\hline Model & OLS & $\begin{array}{l}\text { Fixed } \\
\text { effects }\end{array}$ & $\begin{array}{l}\text { Random } \\
\text { effects }\end{array}$ & $\begin{array}{l}\text { Fixed } \\
\text { effects }\end{array}$ & $\begin{array}{l}\text { Random } \\
\text { effects }\end{array}$ \\
\hline
\end{tabular}

Standard errors in parentheses. Significant at $* * * 1 \%, * * 5 \%, * 10 \%$ on a two-tailed t-test. 
Table 3. Panel Regression Analysis: Inward FDI
(a)
(b)
(c)
(d)

$\begin{array}{lllll}\text { Constant } & -0.051 & -0.622 & -3.086^{* *} & -0.898 \\ & (0.671) & (1.532) & (1.357) & (1.219) \\ \text { RDSUM } & 33.091^{* * *} & 30.248^{* * *} & 50.935^{*} & 74.777^{* * *} \\ & (11.753) & (11.525) & (26.879) & (23.315) \\ \text { RDDIF } & -22.697 & -28.334^{*} & 46.196^{*} & -46.310 \\ & (17.254) & (16.681) & (25.390) & (30.793) \\ \text { ULCDIF } & -1.417 & -- & -0.434 & -1.928 \\ & (1.045) & & (0.757) & (1.936) \\ \text { RULC } & --- & 0.008 & -- & -- \\ & & (0.012) & & \\ \mathrm{K}_{\mathrm{t}-1}\left(10^{-3}\right) & -0.022 & -0.022 & 0.069^{* *} & -0.208^{*} \\ & (0.051) & (0.051) & (0.032) & (0.117)\end{array}$

\begin{tabular}{lllll}
\hline Adjusted $\mathrm{R}^{2}$ & 0.377 & 0.375 & 0.265 & 0.378 \\
\hline No. Observations & 473 & 473 & 93 & 252 \\
\hline Fixed vs. random & 17.71 & 14.44 & 1.82 & 24.83 \\
effects: $\chi^{2}(4)$ & $(0.00)$ & $(0.00)$ & $(0.77)$ & $(0.00)$ \\
\hline Model & Fixed effects & Fixed effects & $\begin{array}{l}\text { Random } \\
\text { effects }\end{array}$ & Fixed effects \\
\hline
\end{tabular}

Standard errors in parentheses. Significant at $* * * 1 \%, * * 5 \%, * 10 \%$ on a two-tailed t-test. 


\section{References}

Almeida P (1996) 'Knowledge sourcing by foreign multinationals: patent citation analysis in the US semiconductor industry' Strategic Management Journal, 17 (Special issue), 155-65.

Baltagi B H (1995) Econometric Analysis of Panel Data, Wiley, Chichester.

Bajo-Rubio, Oscar and Sosvilla-Rivero, Simon (1994), 'An econometric analysis of foreign direct investment in Spain, 1964-89', Southern Economic Journal, 61, 104120.

Barrell, R and Pain, N (1997) 'The Growth of Foreign Direct Investment in Europe' National Institute Economic Review, Issue 160, April, 63-75.

Barrell, R.and Pain, N. (1996) 'An econometric analysis of US foreign direct investment' Review of Economics and Statistics, 78, 200-7.

Beladi H, Co C Y, and Firoozi F (1999) 'Signaling to multinationals: domestic R\&D and inflow of FDI', mimeo, University of Dayton.

Cantwell J (1989) Technological Innovation and Multinational Corporations, Blackwell, Oxford.

Cantwell J (1995) 'The globalization of technology: what remains of the product life cycle model?’ Cambridge Journal of Economics, 19, 155-74.

Cantwell J and Janne O (1999) 'Technological globalisation and innovation centres: the role of technological leadership and location hierarchy' Research Policy, 28, 11944.

Chen, Homi and Chen, Tain-Jy (1998) 'Network linkages and location choice in foreign direct investment', Journal of International Business Studies, 29, 445-467.

Driffield N and Munday M (2000) 'Industrial performance, agglomeration, and foreign direct investment in the UK' Journal of International Business Studies, 31, 21-37.

Dunning J (1988) Explaining International Production, Unwin Hyman, London. 
Dunning, John and Rajneesh Narula (1995) 'The R\&D activities of foreign firms in the United States' International Studies of Management and Organisation, 25, 39-73.

Fosfuri A and Motta M (1999) 'Multinationals without advantages' Scandinavian Journal of Economics, 101, 617-30.

Gassmann, O. and Von Zedtwitz, M. (1999), 'New concepts and trends in international R\&D organisation', Research Policy, 28, 231-250

Håkanson, L. and Nobel, R. (1993), "Determinants of foreign R\&D in Swedish multinationals”, Research Policy, 22, 397-411

Kogut B and Chang S J (1991) 'Technological capabilities and Japanese foreign direct investment in the United States' Review of Economics and Statistics, 73, 40113.

Kuemmerle W (1999a) 'Foreign direct investment in industrial research in the pharmaceuticals and electronics industries - results of a survey of multinational firms’ Research Policy, 28, 179-93.

Kuemmerle W (1999b) 'The drivers of foreign direct investment into research and development: an empirical investigation' Journal of International Business Studies, 30(1), 1-24.

Love J H and Lage-Hidalgo F (2000) 'Analysing the determinants of US direct investment in Mexico’' Applied Economics, 32, 1259-67.

Lucas, Robert E. B. (1993), 'On the determinants of direct foreign investment: evidence from East and Southeast Asia, World Development, 21, 391-406.

Neven D and Siotis G (1996) 'Technology sourcing and FDI in the EC: an empirical evaluation' International Journal of Industrial Organization, 14, 543-60.

Niosi J (1999) 'The internationalization of industrial R\&D: from technology transfer to the learning organization’ Research Policy, 28, 107-17.

Pain, N (1993), 'An econometric analysis of foreign direct investment in the United Kingdom', Scottish Journal of Political Economy, 40, 1-23. 
Patel P and Vega M (1999) 'Patterns of internationalisation of corporate technology: location vs. home country advantages’ Research Policy, 28, 145-55.

Pearce R D (1999) 'Decentralised R\&D and strategic competitiveness: globalised approaches to generation and use of technology in multinational enterprises (MNEs)' Research Policy, 28, 157-78.

Serapio M G and Dalton D H (1999) 'Globalization of industrial R\&D: an examination of foreign direct investments in R\&D in the United States' Research Policy, 28, 303-16.

Soete L (1987) 'The impact of technological innovation on international trade patterns: the evidence reconsidered', Research Policy, 16, 101-130.

Vannoni D (1999) 'Entries and exits in foreign markets: Italian firms’ multinational expansion in the European Union' International Journal of the Economics of Business, 6, 181-196. 